\title{
How Students Solves PISA Tasks: An Overview of Students' Mathematical Literacy
}

\author{
${ }^{1}$ Aan Hendroanto, ${ }^{1}$ Afit Istiandaru, ${ }^{2}$ Nisa Syakrina, ${ }^{1}$ Fariz Setyawan, ${ }^{1}$ Rully Charitas \\ Indra Prahmana, ${ }^{3}$ Agus Sofyan Eka Hidayat \\ ${ }^{1}$ Universitas Ahmad Dahlan, Jl. Ringroad Selatan, Tamanan, Bantul, Daerah Istimewa Yogyakarta, Indonesia \\ ${ }^{2}$ SMP N 3 Mrebet, Jl. Raya Karangnangka, Mrebet, Purbalingga, Indonesia \\ 3Monash University, Scenic Blvd \& Wellington Road, Clayton VIC 3800, Australia \\ e-mail: aan.hendroanto@pmat.uad.ac.id
}

\begin{abstract}
Abstrak
Penelitian ini bertujuan untuk menginvestigasi bagaimana mahasiswa Pendidikan Matematika Universitas Ahmad Dahlan menyelesaikan permasalahan PISA. Penelitian ini menggunakan metode deskriptif dengan pendekatan kualitatif dan didukung dengan data kuantitatif. Sebanyak 20 mahasiswa baru program studi Pendidikan Matematika Universitas Ahmad Dahlan tahun akademik 2016/2017 berpartisipasi sebagai subjek penelitian ini. Instrumen PISA tahun 2012 dialihbahasakan ke Bahasa Indonesia dan selanjutnya digunakan untuk mengumpulkan data kemampuan literasi matematika dan mengidentifikasi kesulitan mahasiswa. Seluruh data dianalisis bedasarkan kerangka PISA. Secara umum, sebanyak 65.7\% mahasiswa mampu memahami permasalahan yang diberikan dan membuat strategi pemecahan masalah. Namun demikian, hanya 46.9\% mahasiswa yang menjawab dengan benar. Selain itu, sebanyak 36.8\% mahasiswa memahami permasalahan level 6 dan 23.7\% diantaranya menjawab pertanyaan dengan benar. Mahasiswa memiliki aktivitas yang baik dalam proses interpretasi terhadap permasalahan individu maupun kelompok. Meskipun demikian, mahasiswa mengalami kesulitan dalam proses merumuskan dan mengerjakan permasalahan yang diberikan terutama yang berkaitan dengan konteks kerja dan sains.
\end{abstract}

Kata kunci: PISA, literasi matematika, penelitian deskriptif

\begin{abstract}
This article aims to investigate how mathematics education students in Universitas Ahmad Dahlan solve PISA mathematics problems. This research used the descriptive method with the qualitative approach and supported with quantitative data. Research subjects were 20 new students of mathematics education at Universitas Ahmad Dahlan in the 2016/2017 academic year. We translated the 2012 PISA instrument and used it to collect data on students' mathematical literacy skills and to identify their difficulties. All the data were analyzed based on PISA's framework. The result shows that, in general, $65.7 \%$ of students were able to understand the problems and plan their strategies to solve them. Meanwhile, only $46.9 \%$ among them could answer correctly. In addition, only $36.8 \%$ of the students were able to understand the level 6 problems while only $23.7 \%$ among them answered correctly. The students performed well in the interpretation process towards the problems with individual and social contexts. However, they found difficulties in the formulation and employment process of the problems, especially in the work and scientific context.
\end{abstract}

Keywords: PISA, mathematical literacy, descriptive research

How to Cite: Hendroanto, A., Istiandaru, A., Syakrina, N., Setyawan, F., Prahmana, R. C. I., \& Hidayat, A. S. E. (2018). How Students Solves PISA Tasks: An Overview of Students' Mathematical Literacy. International Journal on Emerging Mathematics Education, 2(2), 129-138. http://dx.doi.org/10.12928/ijeme.v2i2.10713 


\section{INTRODUCTION}

Based on the results of the recent PISA (Programme for International Student Assessment) evaluations organized by the OECD (Organization for Economic Cooperation and Development) in 2000 and 2003, Indonesia ranked 3rd in the bottom of all participating countries in terms of the students' mathematical literacy ability (Stacey, 2014). On the other hand, along with the results released by OECD, Indonesian students were ranked first in terms of students' motivation to learn mathematics (Stacey, 2014). The motivation of the Indonesian students to study mathematics is far above the average of all participating countries and also above high-ranking countries such as Finland, Japan, and Shanghai (China). These results are quite surprising, especially for experts and researchers in mathematics education.

One of the speculations of why this happened is unfavorable learning strategies and methods in Indonesia (Hendroanto, 2018a). Many mathematics teachers still use traditional approach since their practice tends to be a delivering information speech (Hidayah et al., 2018), without using any attractive media nor promoting the students' mathematics literacy skill. The implementation of strategies and methods of learning becomes successful when it could facilitate the students to reach the learning goals, while the success depends on the competence of teachers (Pepin et al., 2017; Istiandaru et al., 2017; Istiandaru \& Istihapsari, 2017). If a learning aims to promote the students' mathematical literacy, then the teacher should also skilled in mathematical literacy. Therefore, teachers have to also possess sufficient mathematical literacy skill so that the purpose of the developed learning activities can be achieved. This is supported by Stacey (2014) who suggests that the educational system in the high achiever countries in PISA are focusing more towards their teacher training. Considering these facts, Universitas Ahmad Dahlan (UAD) as one of the teacher training university in Indonesia, certainly should be able to prepare prospective mathematics teachers so that they have good mathematical literacy.

Mathematical literacy is defined as an ability to formulate, to use, and to interpret various mathematics problems in daily life (OECD, 2013). There are three main abilities called mathematical processes. They are (1) the ability to formulate mathematics problems, (2) the ability to use appropriate mathematical strategies, and (3) the ability to interpret the solution. In PISA, all these mathematical processes are integrated with mathematical four contents such as change and relationship, space and shape, quantity, and uncertainty and data. They are also integrated with four types of mathematical context (Kamaliyah et al., 2013; Kohar et al., 2014).

In order to prepare prospective teachers with good mathematical literacy based on PISA framework, a deep research on the ability of their current mathematical literacy needs to be done in order to obtain an insight and description of their difficulties to further support them. This information is needed to design learning materials through many processes, one of which is didactical phenomenology (Hendroanto, 2018b). The recent study conducted by Rusmining (2017) in UAD is only focused on investigating students' mathematical literacy based on the aspect of mathematical processes. It is not deep enough to investigate students' ability. Hendroanto (2018a) also investigated mathematics students in UAD to study their difficulties on solving PISA's problems. However, it is not described thoroughly to overview students' mathematical literacy.

Therefore, to further investigate the ability of students in mathematics education in UAD, a deep study on students' mathematical literacy, based on different types of mathematical processes, level of problems, clusters, and many more, is needed. The 
present article aims to investigate and describe thoroughly students' mathematical literacy in mathematics education program, UAD. For these purposes, this study uses PISA 2012 items as a research instrument. This is because the PISA questions are developed to test the participants' mathematical literacy ability and include all types of mathematical processes and abilities. PISA also uses a variety of contexts and mathematical contents to enable a deeper investigation of the difficulties faced by students in developing their mathematical literacy.

\section{RESEARCH METHOD}

This research was conducted in the Mathematics Education Department of Universitas Ahmad Dahlan, which is located at Jalan Ringroad Selatan, Tamanan, Bantul, Daerah Istimewa Yogyakarta. The research subjects were 20 new enrolled students in the 2016/2017 academic year. These 20 students have various level of mathematics ability. This study is a descriptive qualitative research. However, we also used quantitative data with numbers and basic statistics to support arguments and findings in the discussion. Data collection techniques in this study were questionnaire in the form of test, interview, and documentation. The test questionnaire used is PISA 2012 items that have been translated and adapted to local culture and validated by experts. Figure 1, Figure 2, and Figure 3 show some of the examples of the items that have been adapted and translated from the original PISA's problem. To ensure the validity and reliability of data analysis, we conducted a peer review assessment of students' works.

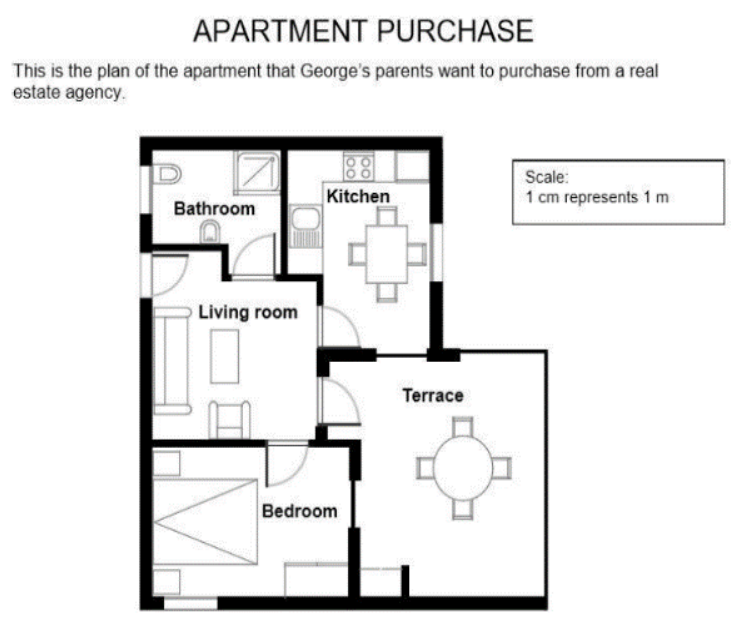

Question 1: APARTMENT PURCHASE

To estimate the total floor area of the apartment (including the terrace and the walls), you can measure the size of each room, calculate the area of each one and add all the areas together.

However, there is a more efficient method to estimate the total floor area where you only need to measure 4 lengths. Mark on the plan above the four lengths that are needed to estimate the total floor area of the apartment

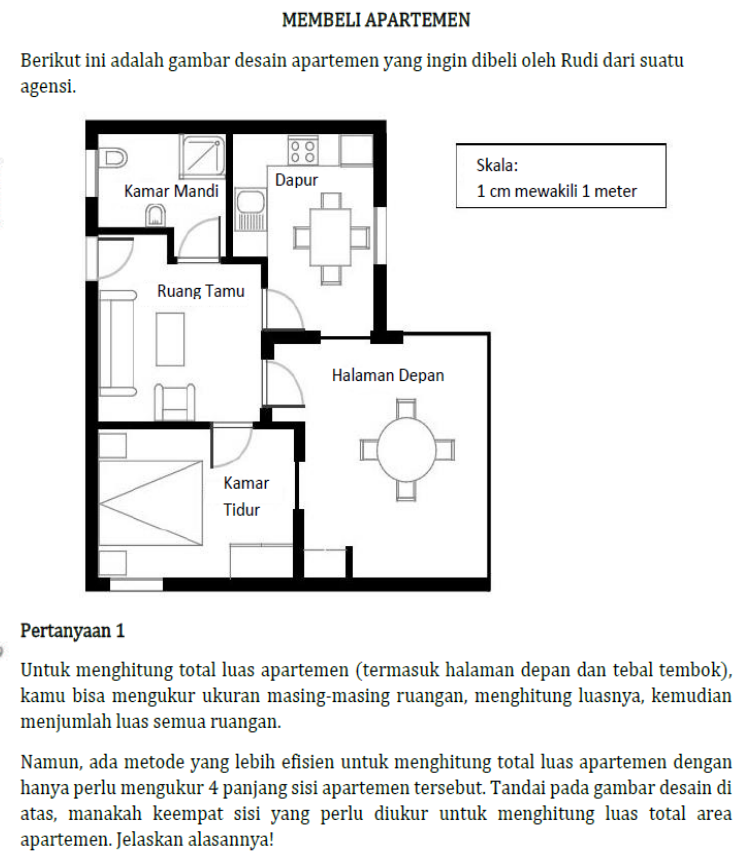

apartemen. Jelaskan alasannya!

Figure 1. Example of problem about apartment purchase

Figure 1 presents the problem addressed to the participants which shows a design of an apartment with the details of the rooms. Normally, to estimate the total area of the apartment, students should find the size of each room, find the area of the rooms, and then sum up all of them. The students, however, were challenged to find only four lengths to estimate the whole area of the apartment as it would be the most efficient method to find the total area, and then provide the reason. 


\section{Question 4: SAILING SHIPS}

Due to high diesel fuel costs of 0.42 zeds per litre, the owners of the ship NewWave are thinking about equipping their ship with a kite sail.

It is estimated that a kite sail like this has the potential to reduce the diesel consumption by about $20 \%$ overall.

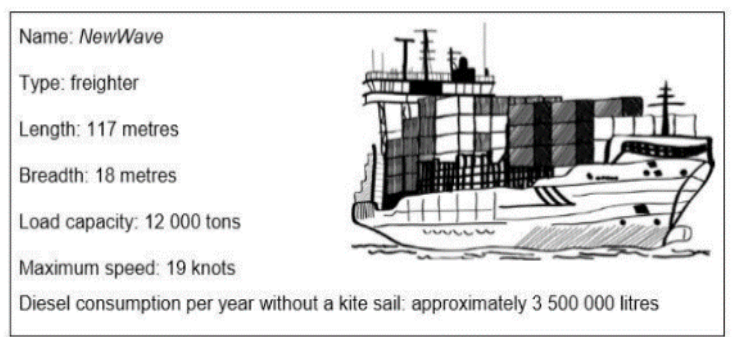

The cost of equipping the NewWave with a kite sail is 2500000 zeds

After about how many years would the diesel fuel savings cover the cost of the kite sail? Give calculations to support your answer.
PM923004-0 19 Pertanyaan 3

Karena harga bahan bakar yang tinggi yaitu 0.42 dollar per liter, pemilik kapal Arjun berpikir untuk melengkapi kapal-kapalnya dengan layang-layang.

Berdasarkan estimasi, penggunaan layang-layang seperti ini dapat mengurangi konsums bahan bakar sebanyak $20 \%$

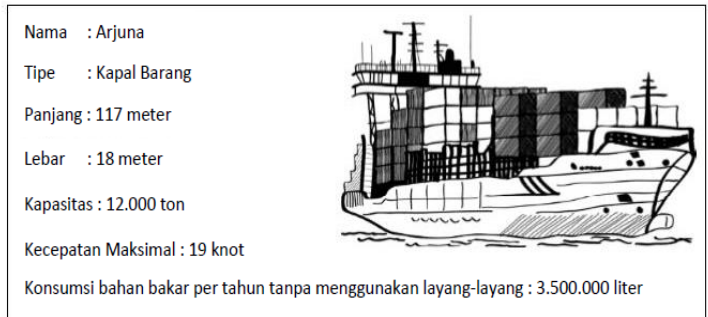

Apabila biaya untuk memasang layang-layang pada Arjuna yaitu 2.500.000 dollar, setelah berapa tahun kah, uang hasil penghematan bahan bakar diesel dapat mengganti biaya pemasangan layang-layang? Tuliskan perhitunganmu untuk mendukung jawabanmu!

Figure 2. Example of problem about sailing ships

Figure 2 presents a problem of sailing ship. The owner of the sailing ship wants to equip the ship with a kite sail since it can reduce the cost of fuel. The size of the ship is given and also the price of the installation. The students were asked to estimate the year when the saving of fuel budget could substitute the price of kite installation.

WHICH CAR?

Chris has just received her car driving licence and wants to buy her first car.

This table below shows the details of four cars she finds at a local car dealer.

\begin{tabular}{|l|c|c|c|c|}
\hline Model: & Alpha & Bolte & Castel & Dezal \\
\hline Year & 2003 & 2000 & 2001 & 1999 \\
\hline $\begin{array}{l}\text { Advertised price } \\
\text { (zeds) }\end{array}$ & 4800 & 4450 & 4250 & 3990 \\
\hline $\begin{array}{l}\text { Distance travelled } \\
\text { (kilometres) }\end{array}$ & 105000 & 115000 & 128000 & 109000 \\
\hline $\begin{array}{l}\text { Engine capacity } \\
\text { (litres) }\end{array}$ & 1.79 & 1.796 & 1.82 & 1.783 \\
\hline
\end{tabular}

Which car's engine capacity is the smallest?

$$
\begin{aligned}
& \text { A. Alpha } \\
& \text { B. Bolte } \\
& \text { C. Castel } \\
& \text { D. Dezal }
\end{aligned}
$$

\section{MEMILIH MOBIL}

Nisa baru saja memperoleh Surat Izin Mengemudi (SIM) dan ingin membelli mobil pertamanya. Tabel berikut menunjukkan informasi detail dari empat mobil yang didapatkan di brosur.

\begin{tabular}{|l|c|c|c|c|}
\hline Model: & Alpha & Bolte & Castel & Dezal \\
\hline Tahun & 2003 & 2000 & 2001 & 1999 \\
\hline $\begin{array}{l}\text { Harga pada iklan } \\
\text { (Dollar) }\end{array}$ & 4800 & 4450 & 4250 & 3990 \\
\hline $\begin{array}{l}\text { Total jarak } \\
\text { penggunaan (km) }\end{array}$ & 105000 & 115000 & 128000 & 109000 \\
\hline $\begin{array}{l}\text { Kapasitas mesin } \\
\text { (Liter) }\end{array}$ & 1.79 & 1.796 & 1.82 & 1.783 \\
\hline
\end{tabular}

Pertanyaan 2

Tentukan manakah mobil dengan kapasitas mesin terkecil?

$\begin{array}{llll}\text { A. Alpha } & \text { B. Bolte } & \text { C. Castel } & \text { D. Dezal }\end{array}$

Figure 3. Example of problem about choosing cars

Figure 3 presents a problem of selecting a car. There are four types of car with each specification. The students were asked to determine the car with the smallest capacity.

Overall, there are 11 items with different context and types. Each item, sometimes, has more than two questions. Students did the work based on the translated problem in Bahasa. However, we did not change the numbers because they have some purpose. Only the currency is also changed into the US dollar since it is already well known among students. 


\section{RESULTS AND DISCUSSION Overview of the Students' Result}

There are three types of mathematical processes in the definition of mathematical literacy. They are (1) process of formulating, (2) process of employing, and (3) process of interpreting (OECD, 2013; Wijaya et al., 2014). In the framework of PISA in 2012, the questions consisted of 7 problems with a focus on the formulating process, 14 problems with the focus on the process of employing and 4 problems on the process of interpretation. We analyzed and identified the students' work based on this three kind of processes. The overall result can be seen in Table 1.

Table 1. PISA test result based on three mathematical processes

\begin{tabular}{cccc}
\hline Type of Processes & Understand & Correct & Wrong \\
\hline Formulate & $52.6 \%$ & $33.1 \%$ & $66.9 \%$ \\
Employ & $66.5 \%$ & $43.6 \%$ & $56.4 \%$ \\
Interpret & $85.5 \%$ & $82.9 \%$ & $17.1 \%$ \\
\hline
\end{tabular}

Table 1 indicates that the students showed a very good result on the problem with the interpretation process. There were $82.9 \%$ of the students who could answer the problem correctly. While in the problems with the process of formulating and the process of employing, the students might have more difficulties because it was only $33.1 \%$ and $43.6 \%$ respectively of all students who were able to solve the problem correctly. In this point of view, the students have good performance on problems related to the interpreting process. On the contrary, the problems related to the formulating process are the most difficult to understand and to solve for the students.

PISA items also consist of various mathematical contents. Based on its framework, there are (1) change and relationship, (2) space and shape, (3) quantity, and (4) uncertainty and data (OECD, 2013; Wijaya et al., 2014). If we look deeper into the instrument, there are 8 questions about space and shape, 7 questions about change and relationship, 4 questions about uncertainty and data, and 6 problems related to quantity. Table 2 shows the result of the students' work analyzed based on the mathematical contents mentioned above.

Table 2. PISA test result based on mathematical content

\begin{tabular}{cccc}
\hline Content & Understand & Correct & Wrong \\
\hline Space and Shape & $50.7 \%$ & $38.2 \%$ & $61.8 \%$ \\
Change and Relationship & $67.7 \%$ & $39.8 \%$ & $60.2 \%$ \\
Uncertainty and Data & $94.7 \%$ & $85.5 \%$ & $14.5 \%$ \\
Quantity & $64 \%$ & $41.2 \%$ & $58.8 \%$ \\
\hline
\end{tabular}

Based on Table 2, the highest achievement is in problems related to uncertainty and data with $85.5 \%$ of the students answered correctly. The other mathematical content problems have almost the same level of result where approximately $60 \%$ of students cannot answer the problem correctly.

Furthermore, PISA 2012 were constructed based on 4 types of contexts, namely (1) individual, (2) work, (3) social, and (4) scientific (OECD, 2013). It also involved 4 aspects of mathematical content: (1) space and shape, (2) change and relationship, (3) uncertainty and data, and (4) quantity (De Lange, 2006; OECD, 2013). The four types of mathematical contexts are scattered in the PISA problems with the proportions of 7 
questions in the context of individuals, 5 questions in the context of work, 7 questions in the social context, and 6 questions in the scientific context.

Table 3. Students' test result based on four types of contexts

\begin{tabular}{cccc}
\hline Type of Contexts & Understand & Correct & Wrong \\
\hline Individual & $74.4 \%$ & $59.4 \%$ & $40.6 \%$ \\
Work & $57.9 \%$ & $29.5 \%$ & $70.5 \%$ \\
Social & $80.5 \%$ & $65.4 \%$ & $34.6 \%$ \\
Scientific & $44.7 \%$ & $25.4 \%$ & $74.6 \%$ \\
\hline
\end{tabular}

From the results in Table 3, we found that the students do not experience much difficulty in individual and social contexts. However, in the work and scientific context, the percentage of the students' correct answers is very low at $29.5 \%$ and $25.4 \%$ respectively. These results indicate that the students have difficulties to understand the problem in the professional work and scientific world which are more complex than the other contexts. This should be a concern since the students in mathematics education are projected to be professional teachers and should be capable to deal with similar situations in the context of work and scientific issues.

In terms of PISA level, the analysis shows that the students are only able to answer most of the questions in the range of level 1 to level 3. This result can be seen in Table 4 where $82.5 \%$ students could answer the problems correctly at level 1 , $70.2 \%$ at level 2 , and $73.7 \%$ at level 3 . Only $36.8 \%$ of the students were able to solve the level 6 problems and $40 \%$ of students were successful at level 4 and 5 . These results indicate that students were still less capable in selecting, comparing, and evaluating strategies to solve complex problems and using broad thinking and reasoning, then connecting knowledge and skills effectively to mathematics according to the situation at hand (OECD, 2013; Wijaya et al., 2014).

Tabel 4. Students' test result based on the level of the problems

\begin{tabular}{cccc}
\hline Level & Understand & Correct & Wrong \\
\hline Level 1 & $82.5 \%$ & $71.9 \%$ & $28.1 \%$ \\
Level 2 & $70.2 \%$ & $57.9 \%$ & $42.1 \%$ \\
Level 3 & $73.7 \%$ & $51.3 \%$ & $48.7 \%$ \\
Level 4 & $56.1 \%$ & $33.3 \%$ & $66.7 \%$ \\
Level 5 & $47.4 \%$ & $17.5 \%$ & $82.5 \%$ \\
Level 6 & $36.8 \%$ & $23.7 \%$ & $76.3 \%$ \\
\hline
\end{tabular}

PISA distinguishes 3 clusters groups in PISA questions: (1) reproduction, (2) connection, and (3) reflection (Wijaya et al., 2014). In the reproduction group, students are able to recognize facts, objects and their properties, equivalent, using routine procedures, standard algorithms, and technical skills. While in the reflection group, students can make connections between ideas in mathematics and integrated information to solve a problem. In the reflection group, students are required to be able to identify and find the mathematical ideas behind the context of the given problem. The reflection competence is the highest level in PISA. In the instrument used in this study, there 9 items categorized as reproduction problem, 10 items as connection problems and 6 items as reflection problem. Table 5 presents the result of students' works based on cluster groups. 
Tabel 5. Students' test result based on the cluster of the problem

\begin{tabular}{cccc}
\hline Cluster & Understand & Correct & Wrong \\
\hline Reproduction & $73.7 \%$ & $59.1 \%$ & $40.9 \%$ \\
Connection & $71.6 \%$ & $49.5 \%$ & $50.5 \%$ \\
Reflection & $43.9 \%$ & $24.6 \%$ & $75.4 \%$ \\
\hline
\end{tabular}

From the analysis result in Table 5, it is found that most of the students are in the category of a cluster of reproduction and connection where each of them is $73.7 \%$ and $71.6 \%$ respectively. However, the students have not been very good at solving the problems in the cluster because only $59.1 \%$ and $49.5 \%$ in each cluster who could solve the problems correctly. The reflection cluster became the lowest group because only $43.9 \%$ of the students were able to understand and only $24.6 \%$ were able to answer the problem correctly.

\section{Example of Students' Answers}

The analysis of students' difficulties also supports the findings of students' mathematical literacy (Hendroanto, 2018a). Many students' answer was far from what was asked. One of the examples can be seen in Figure 4. The question asked students to select only 4 sides of an apartment to be measured so that they can calculate its area (see Figure 1). In the answer, many students actually look for the area of the apartment. This finding indicates that students were difficult to understand the problem and struggled to formulating process.

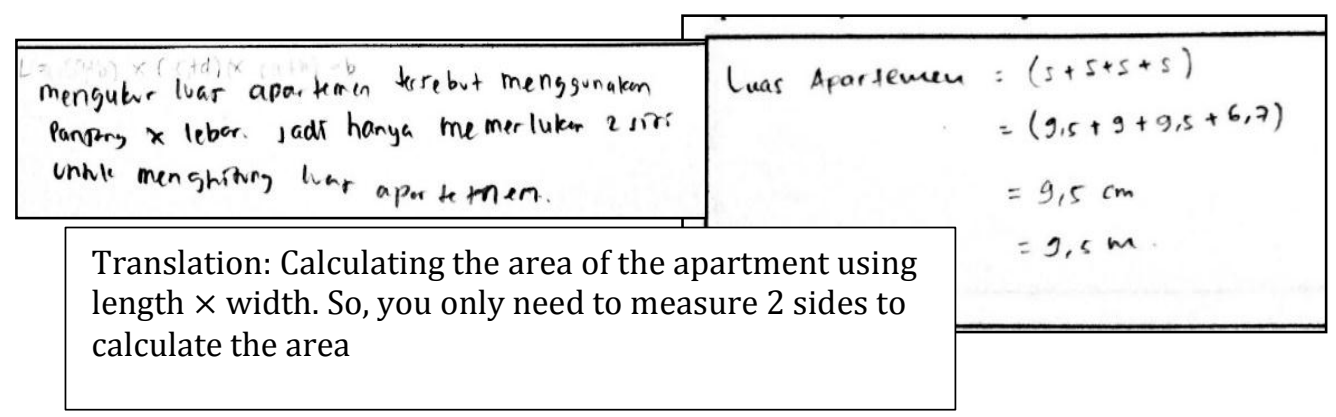

Figure 4. Example of student's misunderstanding of the problem

Look at student's answer in Figure 5, the problem asked students to calculate how many years they need to get the amount of money to install a kite system on a ship (see Figure 2). There are students who actually use 3,500,000 as the amount of money for using fuels in one year while that number actually is the volume of fuels needed per year. We can clearly see that students are struggling to select relevant information so that they can solve the problem. This is one of the high-level questions because of the number of information presented. In this case, students mostly fail to solve high-level question because they cannot select relevant information. 


\begin{tabular}{|c|c|}
\hline 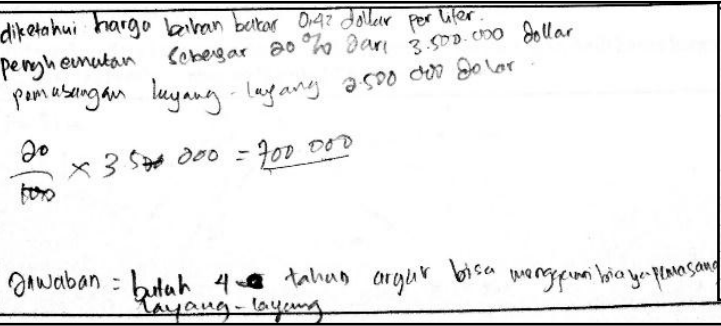 & 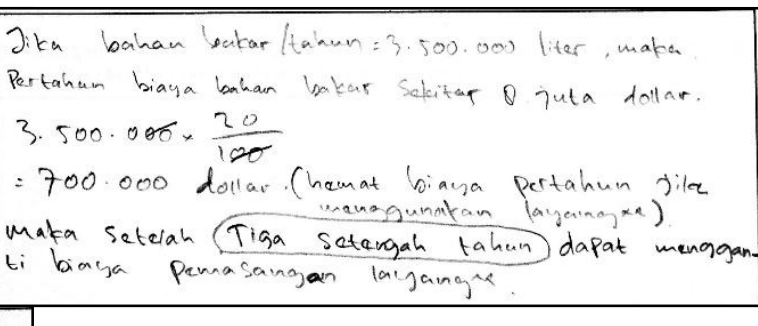 \\
\hline $\begin{array}{l}\text { Translation: The price of the fuel is } 0,42 \\
\text { dollar per liter } \\
\text { Fuel saving is } 20 \% \text { of } 3.500 .000 \text { dollar } \\
\text { Instalment cost is } 2.500 .000 \text { dollar } \\
\qquad \frac{20}{100} \times 3500000=700000 \\
\text { Answer: } 4 \text { years needed to cover the } \\
\text { instalment cost }\end{array}$ & $\begin{array}{l}\text { Translation: if the price of the fuel per year is } \\
3.500 .000 \text { liter, then per year the cost is } 8 \\
\text { million dollar. } \\
3.500 .000 \times \frac{20}{100} \\
=700.000 \text { dollar } \\
\text { (fuel saving per year if using the kite.) } \\
\text { Then after three and a half year can cover the } \\
\text { installment cost }\end{array}$ \\
\hline
\end{tabular}

Figure 5. Example of student's answer in using irrelevant information

Lack of understanding and digesting the information provided on the problem is also a concern (see Figure 6). For example in Figure 3, they are asked to choose which car has the smallest machine capacity. Many students are wrong in picking information to compare the machines. Instead of comparing the capacity of each machine, they answered the car with medium or large capacity because they compare the other aspects. Actually, this is a trivial error but the impact is quite significant in determining the final result. Although this is an easy question, some students are failed to answer correctly. In relation with the interpretation process and mathematical content of change and data, some students have low literacy in this kind of problem.

\begin{tabular}{|c|c|c|c|c|c|}
\hline Model: & Alpha & Bolte $J$ & Castel & Dezal & Pertanyaan 2 \\
\hline Tahun & $2003 \checkmark$ & $2000 \checkmark$ & $2001 \checkmark$ & 1999 & \multirow{2}{*}{$\begin{array}{l}\text { Tentukan manakah mobil dengan kapasitas mesin terkecil? } \\
\begin{array}{llll}\text { A. Alpha } & \text { B. Bolte } & \text { C. Castel } & \text { D. Dezal }\end{array}\end{array}$} \\
\hline $\begin{array}{l}\text { Harga pada iklan } \\
\text { (Dollar) }\end{array}$ & 4800 & $4450 \sqrt{ }$ & 4250 & $3990^{\checkmark}$ & \\
\hline $\begin{array}{l}\text { Total jarak } \\
\text { penggunaan }(\mathrm{km})\end{array}$ & 105000 & $115000^{v}$ & 128000 & $109000^{2}$ & Sawabannya : Alpha. \\
\hline $\begin{array}{l}\text { Kapasitas mesin } \\
\text { (Liter) }\end{array}$ & 1.79 & 1.796 & 1.82 & 1.783 & Which car has the smallest machine capacity? \\
\hline
\end{tabular}

Figure 6. Student's answer in the problem of finding machine with the smallest capacity

In addition to the above examples, the creativity of student to choose a strategy or a method to solve the problem is also lacking. Many students cannot determine the method or strategy to solve the problem and just write "confused" on the answer sheet. For instance, in one of the questions, the student should look for the length of the kite strap but they were not able to find the right method to complete. In another problem of relating the circles under the context of Bianglala, they write on the answer sheet that they forgot the formula to solve the problem while this problem is actually can be solved even without a formula. But they just give up trying a method or a strategy. On the other problem, students are unable to find a method to calculate the speed of the wind on kites which is $25 \%$ faster than the speed of the wind on the vessel. In the end, they concluded that $25 \%$ of the vessel's speed is the answer. Although these questions are categorized as easy for higher education students, they 
still have many difficulties. This finding is related to the process ability of the students. They are struggled to choose which strategy or method to solve the problems.

From the analysis result of student's answer, we also have some findings. Firstly, students are less able to perform the formulation process because this process requires good reasoning ability to identify problems, create mathematical models and select information and elements involved. In the use of information to solve the problem, there are still many errors found. Secondly, the lack of understanding of students in digesting the information given to the problem and process it. Many students are wrong in using methods or selecting information that will be used. Finally, the students' creativity ability is still lacking, so many students cannot determine the method or strategy to solve the problem. Though the problems faced include easy categories for student level.

\section{CONCLUSION}

In general, the mathematical literacy of the new students of mathematics education department of Universitas Ahmad Dahlan in the 2016/2017 academic year is low. They are less capable to understand the problem and determine how to solve the given problem. For a college student, this result is very less than expected. Moreover, if we look at the problem, PISA was actually intended for school students. Meanwhile, in terms of PISA level, students are mostly located in the range of level 1 to level 3. Only some students managed to level 5 and 6.

In terms of aspects of mathematical literacy, students demonstrated good performance on problems with the interpretation process, but in the process of formulating and process of employment, students still found difficulties. Good performance is also found in problems with individual and social contexts. However, in the work context and scientific context, students are not good enough in understanding and solving the problems. This should be a concern since students of mathematics education themselves are projected to be professional teachers who are capable of facing similar situations in the context of work and scientific issues. Most students are grouped in the clusters of reproduction and connection. However, they still has not been very good at solving the problems within these clusters correctly. The reflection cluster becomes the lowest because few students are able to understand and answer correctly the question in this cluster.

\section{REFERENCES}

De Lange, J. (2006). Mathematical Literacy for Living from OECD-PISA Perspective. Tsukuba Journal of Educational Study in Mathematics, 25(1), 13-35.

Hendroanto, A. (2018a). Analisis Kesulitan Mahasiswa Baru Pendidikan Matematika dalam Mengerjakan Soal PISA. APOTEMA Jurnal Pendidikan Matematika, 4(1), 1-7.

Hendroanto, A. (2018b). Didactical Phenomenology untuk Mengembangkan Aktivitas Pembelajaran Geometri Bidang dengan Pendekatan Pendidikan Matematika Realistik. Prosiding Seminar Nasional Pendidikan Matematika Etnomatnesia. Yogyakarta: Universitas Sarjanawiyata Tamansiswa.

Hidayah, I. Dwijanto, \& Istiandaru, A. (2018). Manipulatives and Question Series for Elementary School Mathematics Teaching on Solid Geometry. International Journal of Instruction, 11(3), 649-662. 
Istiandaru, A., \& Istihapsari, V. (2017). Persepsi Mahasiswa Calon Guru Matematika terhadap Penggunaan Alat Peraga Manipulatif. INSPIRAMATIKA, 3(2), 98-105.

Istiandaru, A., Istihapsari, V., Prahmana, R. C. I., Setyawan, F., \& Hendroanto, A. (2017). Characteristics of Manipulative in Mathematics Laboratory. Journal of Physics: Conference Series, 943(1), 012023.

Kamaliyah, K., Zulkardi, Z., \& Darmawijoyo, D. (2013). Developing the Sixth Level of PISA-like Mathematics Problems for Secondary School Students. Journal on Mathematics Education, 4(1), 9-28.

Kohar, A. W., Zulkardi, Z., \& Darmawijoyo, D. (2014). Developing PISA-like Mathematics Tasks to Promote Students' Mathematical Literacy. Proceeding $2^{\text {nd }}$ SEA-DR. Palembang: Universitas Sriwijaya.

OECD. (2013). PISA 2012 Assessment and Analytical Framework: Mathematics, Reading, Science, Problem Solving and Financial Literacy. Paris: OECD Publishing.

Pepin, B., Xu, B., Trouche, L., \& Wang, C. (2017). Developing a Deeper Understanding of Mathematics Teaching Expertise: An Examination of Three Chinese Mathematics Teachers' Resource Systems as Windows into Their Work and Expertise. Educational Studies in Mathematics, 94(3), 257-274.

Rusmining. (2017). Analysis of Mathematics Literacy of Students of Mathematics Education Department Viewed from Process Components. Unnes Journal of Mathematics Education, 6(3), 384-390.

Stacey, K. (2014). The PISA View of Mathematical Literacy in Indonesia. Journal on Mathematics Education, 2(2), 95-126.

Wijaya, A., van den Heuvel-Panhuizen, M., Doorman, M., \& Robitzsch, A. (2014). Difficulties in Solving Context-based PISA Mathematics Tasks: An Analysis of Students' Errors. The Mathematics Enthusiast, 11(3), 555-584. 